\title{
A VIDA DOS PINGÜINS
}

Airton PaschOA

A

dificuldade reside na oração seguinte. Mas pode, pode ser boa, sem dúvida. Sem dúvida que pode trair suspeita a adversativa. Mas a alusão pode pôr o pingo nos is. Ilusão? Tem apenas um i. Mas pode. Pode ser. Fica até mais fácil, sem dúvida. Sem dúvida que tem pingos sem is. Mas são pingos... pingos sem is? E pingos com is - pingüins? Não trema, é piada. Mas pode. Pode ser boa. A dos pingüins pelo menos. Pelo menos. Mas pingüim pode ter pelo? Pode. Pingüim pode. Menos ovo. Ovo não. A adversativa pode chocar. E a descrição ser fatal.

\section{A VIDA DOS PINGÜINS II}

Não é que o frio não incomoda. Incomoda. Mas a gente se acostuma. Depois, tem as rodas... Não é pra isso que servem as rodas? Calorosas como são, confortam. Francamente, até demais. A ponto de, queimado, buscar abrigo no frio. Não que o frio não incomoda. Incomoda. Mas conforta. Quase tanto quanto incomoda. E conforta. Francamente.

\section{A VIDA DOS PINGÜINS III}

Na beirada para, ave, azul profundo. Abobada da abóbada, estufa o peito, abre as asas e - escorrega de barriga. Levanta, bate a roupa e sai andando que nem o Carlitos. Tem graça desgraça? Quando é um só, pode ter. Mas pingüim é um? Hum... Que nem no cheque? Pode ser — hum bilhão de pingüins reais! E pingüim é real? Por que não? Que nem falcão? É, que nem falcão. É só estufar o peito, peregrino, abrir as asas e - pingüim tem asa? 


\section{A VIDA DOS PINGÜINS III I/II}

Ter, ter, não tem, mas avoa também. Que nem falcão? Que nem pato. Pato? É, que nem pato, pato, sim, quando não quer espatifar o patife.

\section{A VIDA DOS PINGÜINS IV}

E se de repente cai um aqui e ali também não é o fim do mundo. Cá a fila cáfila? Mas cáfila não é fila de camelo? A vida dos camelos? Camelo tem poesia? Tem corcova... E corcova tem poesia? Pode ter. Tem cor, tem cova... Cor de cova? Cinza, preto, branco... A cor dos pingüins? Pode ser - corcova. Pingüim tem corcova? Pode, pode ter. Mas uma só. Só uma? Só. Senão não é pingüim. E tem que sair da fila.

\section{A VIDA DOS PINGÜINS V}

Impossível. Elevar as asas, sem tirar os pés do chão, até a altura do cocuruto e ainda por cima, como se dotadas de garra, agarrá-lo pelas raízes, como quem quer se erguer pelo próprio escalpo, só que sem a impulsão natural, e passar apenas a arranhá-lo, de lá pra cá, daqui pra lá, de cima pra baixo, de baixo pra cima, da esquerda pra direita, da direita pra esquerda, pra frente e pra trás, em círculos, em todos os sentidos, enfim. Impossível. Quase tanto quanto deixar de tentá-lo. Coçar a cabeça exige uma revolução. 
216 Literatura e Sociedade

\section{A VIDA DOS PINGÜINS VI}

Abraçar o mundo? Oferecer-se ao sacrifício? Parar o trânsito? Pedir por socorro? O que significa abri-los? Não digo assim, que não consigo escrever, mas abrir os braços é, sim, confesso, nossa grande dificuldade, a maior aliás dentre as tantas que enfrentamos. E quando conseguimos finalmente operar o milagre, avulta tão prodigiosamente nosso embaraço que logo aborrecemos o impulso equívoco. Tenho por vezes que pode não ser, Deus me perdoe, senão expressão de espreguiçar sem fim...

\section{A VIDA DOS PINGÜINS VI I/II}

Manter quiçá o equilíbrio? O desconjunto vive por um fio, quem não sabe? desde o primeiro bracejar. Mas depende de fato, meu receio, de abrir assim os braços?

\section{A VIDA DOS PINGÜINS VII}

Mas quando damos sorte, mercê do piso liso, e não aterrizamos de barriga, quando finalmente estatelamos de costas, receio que nubla a vista o susto, ou o instinto de conservação, sei lá, e voltamos voando a rastejar de pé. E no entanto existe, o azul existe, visto que o acusa o pálido reflexo no gelo. Um mortal pra trás, fico pensando, permitia quem sabe entrevê-lo de relance, mas e a coragem? Um torcicolo podia ajudar também, de esguelha que fosse, mas, postulado o pescoço, quantos já não perderam a cabeça? Metê-la entre as pernas e do fundo dos fundilhos... Mantê-la no lugar, preciso, nem que seja a martelo. 